\title{
Halla-ahon ahdistus ja ironia
}

\section{Ulossulkeva suomalaisuus ja ahdas nationalismi Scripta-blogissa}

Perussuomalaisten puheenjohtaja Jussi Halla-aho tuo toistuvasti esille pelkoaan siitä, että suomalainen yhteiskunta muuttuu. Hän maalaa uhkakuvaa, jossa "islamisaatio" ja "väestönvaihto" tuhoavat Suomen kansan (esim. Halla-aho 2015; Suomen Uutiset 2018; Torvinen 2019). Hallaaho on käsitellyt näkemyksiään länsimaisen kulttuurin uhanalaisuudesta jo viidentoista vuoden ajan blogissaan Scripta - Kirjoituksia uppoavasta lännestä. Vuonna 2005 aloitetun blogin keskeinen teema on maahanmuuttovastaisuus. Juuri Halla-aho on tuonut islamisaation käsitteen ja monien Länsi-Euroopan maiden populistipuolueiden edistämän islamvastaisuuden (Maussen ja Grillo 20I4: I8I) suomalaiseen keskusteluun. Blogin nimeen tiivistyy se, mistä on kysymys: ahdistuksesta, joka johtuu siitä, että Suomen valtiolaiva on uppoamassa, kuten koko länsimainen kulttuurimme.

Halla-aho sai blogikirjoitustensa perusteella tuomion kiihottamisesta kansanryhmää vastaan 2000 -luvun alussa. Kirjoitukset nousevat edelleen toistuvasti esille julkisuudessa, viimeksi kevään 2019 eduskuntavaalien yhteydessä (Ilta-Sanomat 2019). Halla-aho on puolustanut provokatiivisia blogitekstejään vetoamalla sananvapauteen ja siihen, että hän kirjoitti ne eri asemasta käsin kuin missä hän on tänä päivänä (Iltalehti 2019). On totta, että monet julkisuudessa esille nostetut kirjoitukset on julkaistu ennen kuin Halla-ahosta tuli valtakunnallisella tasolla vaikutusvaltainen poliitikko. Blogi oli kuitenkin se astinlauta, jonka avulla hän nousi netin seuraajakunnan "mestarista" puolueen johtoon (Horsti ja Nikunen 2013; Horsti ja Saresma 2020) ja toi maahanmuuttovastaisuuden suomalaisen politiikan agendalle.

Halla-ahon poliittinen ura rakentuu kansallismieliselle ideologialle, jonka keskiössä ovat maahanmuuton ja monikulttuurisuuden vastustaminen, eikä hän ole saamastaan tuomiosta huolimatta missään vaiheessa irtisanoutunut varhaisissa kirjoituksissaan esittämistään rasistisista mielipiteistä (Stenroos ja de Fresnes 2017). Nykyisin hän vaikuttaa Twitterissä blogia aktiivisemmin, mutta jatkaa kohun herättämistä (ks. esim. Paananen 2019; Pullinen 2019). Hänen toimintaansa voi tulkita kaksoispuheen näkökulmasta.

Kaksoispuhe toimii Tuula Vaarakallion (2017) mukaan niin, että eri foorumeilla puhutellaan eri yleisöjä: politiikan valtajulkisuudessa tai vaikkapa eduskunnassa käyttäydytään ja puhutaan maltillisemmin, mutta sosiaalisessa mediassa ja omien kannattajien edessä käytetään ronskimpaa kieltä ja esitetään tiukempia näkemyksiä. Blogi on Halla-aholle alusta, jossa hän voi tuoda esiin näkemyksiään kärjekkäämmin kuin valtakunnan mediassa puolueensa johtajana. Blogia ja sen sanomaa on tutkittu kriittisestä näkökulmasta (esim. Keskinen 20I2; Nikunen 20I5; Saresma 
2017a), mutta blogin tarkka systemaattinen analyysi on tarpeen, sillä siihen tiivistyy eri puolilla Eurooppaa ja Yhdysvalloissa suosiotaan kasvattavan oikeistopopulismin retoriikka, jossa nationalismia nostatetaan affektiivisesti (Pettersson 2017: 28).

Populismia ja oikeistopopulismin ja nationalismin suhdetta on tutkittu paljon (Brubaker 2020) ja on aivan oikein huomautettu, että ne eivät ole sama asia (Ylä-Anttila 2017). Tässä tarkastelemme kuitenkin juuri nationalistista oikeistopopulismia sellaisena kuin sen Jussi Halla-ahon blogissa näyttäytyy. Halla-ahon asema suomalaisessa politiikassa on vahvistunut, ja tällä hetkellä hän on vaikutusvaltainen oppositiojohtaja. Artikkelin erityisyys on siinä, että eri foorumeilla esitettyjen äärioikeistolaisten mielipiteiden tai Hommaforumin keskustelun sijaan tarkastelemme politiikan kärkikaartiin nousseen Halla-ahon blogia systemaattisesti. Analysoimme Maussenin ja Grillon (20I4: 178) kehotuksen mukaisesti empiirisesti ja kontekstuaalisesti oikeistopopulistisen retoriikan toimintaa. Yhdistämällä oikeistopopulismin, nationalismin, affektiivisuuden ja retorisen tyylin tutkimisen pystymme osoittamaan, miten affektit toimivat performatiivisesti tässä blogissa, jota voi hyvällä syyllä kutsua suomalaisen oikeistopopulismin ja maahanmuuttovastaisuuden syntysijaksi.

Populistisen retoriikan ja tunteiden performatiivisuuden yhteyden tarkasteleminen on yhä tärkeämpää nykyisessä yhteiskunnallisessa tilanteessa, jossa politiikka polarisoituu radikaalioikeistoon ja arvoliberaaliin vasemmistoon. Sosiaalisessa mediassa käydään yhä tiukempaa ideologista kamppailua, jonka käyttövoimaksi affektit on valjastettu. Keskittyessään affekteihin ja erityisesti vihan, inhon ja pelon mobilisoivaan voimaan artikkeli jatkaa suomalaisessa tutkimuksessa vielä melko vähäistä "huonojen tunteiden" tutkimusta (Kivimäki et al. 20I0: 4). Sen lisäarvo on oikeistopopulistisen retoriikan tutkiminen systemaattisesti lukemalla yhtä - joskin erittäin vaikutusvaltaista - tekstikorpusta performatiivisuuden ja affektiivisuuden yhdistävästä näkökulmasta. Lähiluvun avulla osoitamme, että pintapuolisesti viileän rationaalista argumentaatiota voi tulkita vihapuheena, joka pyrkii hiljentämään poliittiseen keskusteluun osallistuvia ja näin rapauttamaan demokratian toimintaa. Purkamalla Scriptan argumentaation ja viestin osiinsa osoitamme, mihin tyylikeinoihin sen affektiivinen vaikutus perustuu. Samalla osallistumme ajankohtaiseen keskusteluun vihapuheen vaikutuksista. Esitämme, että blogi ei ole sananvapauden pyhättö vaan ihmisten tunnereaktioita hyödyntävä keino käyttää valtaa.

\section{Käsitteet ja teoriat}

Tässä artikkelissa tarkastelemme Halla-ahon Scriptaa analysoiden blogipostausten affektiivisuutta, tyyliä, retoriikkaa ja performatiivisuutta. Kysymme Sara Ahmedin (20I8) lailla, mitä tunteet tai affektit tekevät, miten niitä käytetään jopa strategisesti jonkin asian puolesta tai jotakin vastaan (ks. myös Kivimäki et al. 20l0: 3). Tarkastellessamme blogien affektiivisuutta emme Ahmedin tapaan erota tunteita ja affekteja: myös 
affektit ovat tarkastelussamme diskursiivisia ja myös tunteilla on materiaalisuutensa. Sosiaalisen median keskustelut ovat affektiivisia ja performatiivisia: ne liikuttavat ja aikaansaavat vaikutuksia. Sara Ahmed kuvaa Tunteiden kulttuuripolitiikassa (2004, suom. 20I8) sitä, kuinka affektiiviset tekstit järjestävät ihmisiä yksilöinä ja ryhmien jäseninä. Tarkastelemme keskusteluja teksteinä, jotka vaikuttavat performoimalla tunteita. Affektit eivät ole tai sijaitse teksteissä, vaan ne tulevat oleviksi, kun ne nimetään ja kohdistetaan johonkin tai joihinkin. Näin tapahtuu esimerkiksi, kun asettamme teksteissä kuvattavat toiset pelkojemme lähteiksi. Tunteet ovat siten yliyksilöllisiä, ne ovat yhteiskunnallisesti, kulttuurisesti ja historiallisesti tuotettuja (Kivimäki et al. 2010: 4), ne koetaan suhteessa toisiin ja ne suuntautuvat intentionaalisesti kohti toisia (ks. myös Saresma 2020). Yliyksilölliset affektit tuottavat Ahmedin (2018: 58-59) mukaan sekä subjektinsa että kohteensa.

Affektit toimivat sosiaalisessa mediassa tehokkaasti synnyttäen esimerkiksi maahanmuuton vastustamisen ympärille vihan tai ahdistuksen yhteenliimaamia yhteisöjä (Saresma 2020). Tällaiset tunneyhteisöt rakentuvat kierrättämällä tiettyjä ideologisia sisältöjä, kuten kiihkonationalismia ja muukalaisvihaa, ja diskursiivisia käytäntöjä, kuten ironiaa. Ahmedin (2018: 82) tavoin ajattelemme, että Halla-ahon blogissa performoidut tunteet kiertävät, leviävät ja tarttuvat. Pelko ja viha, jotka liittyvät uhkaavaksi koettuihin muukalaisiin maahanmuuttokeskusteluissa, ovat tahmeita ja tarttuvia tunteita. Ahmedia tulkiten pelon ja vihan tahmeus tarkoittaa sitä, että ne tarttuvat toisiinsa ja tarrautuvat niiden kanssa kosketuksiin joutuviin ihmisiin. Tahmaisuus viittaisi Ahmedia edelleen lainaten myös "toisten", tässä maahanmuuttajien, kehoihin, joista tulee abjekteja. Affektit liimaavat tai kiinnittävät maahanmuuttajiin tiettyjä merkityksiä. Ja vielä tahmaisuus voi tarkoittaa sitä, että nurkkakuntainen kansallismielisyys tahmaa yhä uusia alueita blogin affektiivisen ilmaisun tarttuessa ja levitessä.

Tyylikeinoista kiinnitämme erityistä huomiota ironiaan (Hutcheon 1994), joka on Halla-aholle ja maahanmuuttovastaiselle puhetavalle tyypillistä (Nikunen 2015). Linda Hutcheon (1986: 94-96) käyttää käsitettä kaksoisyleisö (double audience) selittämään sitä, miksi jotkut ymmärtävät tekstin ironian, mutta toiset eivät. Ironian teho perustuu juuri tähän. Ymmärtääkseen ironian lukijan on pystyttävä tekemään ero sen välillä, mitä tekstissä sanotaan eksplisiittisesti ja mihin vain vihjataan rivien väleissä. Hyödynnämme Hutcheonin kaksoisyleisöjen ja Vaarakallion (2017) kaksoispuheen käsitteitä tarkastellessamme Halla-ahon blogin affektiivista ilmaisua.

Blogin retoriikassa meitä kiinnostaa se populistinen logiikka, jolla kirjoittaja tuottaa jakoa "meihin" ja "muihin" ja konstruoi tämän rajanvedon kautta (kuvitteellista) suomalaisuutta. Populistisen viestinnän keinoja ovat käsiteltävän asian yksinkertaisena esittäminen, tunteiden herättäminen pikemmin kuin järkeen vetoaminen sekä viestin toistaminen yhä uudelleen (Rautio 2019). Populismi itsessään on Ernesto Laclaun (2005; ks. Palonen ja Saresma 2017) mukaan tyhä ideologia, joka kiinnittyy muihin ideologioihin. Populismi ei välttämättä liity esimerkiksi rasismiin, mutta se voi kietoutua äärioikeistolaisiin fantasioihin valkoisesta ylival- 
lasta. Erityisesti oikeistopopulismi kiinnittyy usein muukalaisvihaan ja maahanmuuttovastaisuuteen.

On tärkeää tehdä ero populismin ja nationalismin välille (Brubaker 2020; Ylä-Anttila 2017). Joidenkin mielestä ne liittyvät kiinteästi yhteen. Monet Euroopan maahanmuuttovastaiset puolueet, joiden nationalismi tiivistyy muukalaisvihaksi ja nativismiksi, on leimattu populistisiksi. Tutkijat kuten Stavrakakis et al. (2017) puolestaan korostavat populismin ja eksklusiivisen nationalismin eroa, sillä 'kansa' määritellään niissä eri tavoin: populismissa se on altavastaajana eliitin ikeessä, nationalismissa kansa on kansakunta. Brubakerin oman näkemyksen mukaan populismia ja nationalismia on syytä tarkastella analyyttisesti erillisinä, mutta ei kuitenkaan toisistaan täysin riippumattomina. (Brubaker 2020: 45.)

Jaamme Brubakerin ymmärryksen populismista ja nationalismista ilmiöinä, jotka eivät ole täysin päällekkäisiä, mutta jotka voivat kietoutua tosiinsa - kuten Jussi Halla-ahon blogissa. Nationalistinen radikaalioikeisto on lähtökohtaisesti maahanmuuttajia vastaan, ja esimerkiksi Hallaahon Scriptan pohjalta syntyneellä Hommaforumilla se on keskeinen yhdistävä tekijä (Vänni 2009). Maahanmuuttokeskustelu on affektiivista ja siinä mobilisoidaan inhon ja häpeän kaltaisia "pahoja" tunteita (Nikunen ja Pantti 2018). Sosiaalinen media on yhä tärkeämpi äärioikeistolaisen, kansallismielisen sanoman levittämisen väline. Muukalaisvastaisen puhetavan levitessä internetissä ja tihkuessa yhteiskunnalliseen keskusteluun puhetapa myös normalisoituu. (Pettersson 2017; Saresma 2020.)

Katarina Pettersson (2017: 6) esittää perussuomalaisten ja ruotsidemokraattien kansallismielistä poliittista blogidiskurssia tarkasteltuaan, että poliittiset blogit ovat "ihanteellinen ympäristö kansallismieliselle poliittiselle viestinnälle ja suostuttelulle", sillä ne "mahdollistavat voimakkaiden, uskottavien ja tunteisiin vetoavien viestien välittämisen", vaikka ne samalla suojelevat rasistisiakin näkemyksiä jakavaa bloggaajaa rasismisyytöksiltä sillä perusteella, että tämä keskustelee ikään kuin neutraalisti, ilmaisematta omaa kantaansa rasismiin. Niko Hatakka (2019) puolestaan tarkastelee populistisen radikaalioikeiston toimintaa hybridissä mediasysteemissä, jossa informaatiota (ja myös disinformaatiota ja propagandaa) levittävät eri julkisuuden alueilla eri tahot ja myös eriääniset toimijat. Perinteisen median, sosiaalisen median ja vaihtoehto- tai "valemedian" muodostama hybridi mediasysteemi tarjoaa erilaisille toimijoille mahdollisuuden osallistua merkityksenmuodostukseen ja tiedontuotantoon, mutta myös informaation levittämiseen ja sen uudelleenkehystämiseen (mt.: 48). Petterssonin ja Hatakan tutkimukset auttavat ymmärtämään Halla-ahon blogin tehoa nationalistisen viestin vahvistamisessa.

Halla-ahon blogia suomalaisen maahanmuuttovastaisen liikehdinnän yhteydessä on tutkittu jonkin verran (Horsti ja Nikunen 2013; Horsti ja Saresma 2020; Keskinen 2012; Saresma 20I7a; Vänni 2009). Samoin on analysoitu Halla-aholle ja koko maahanmuuttovastaiselle liikehdinnälle ominaista ironista tyyliä (Nikunen 20I5) ja maahanmuuttokeskustelun affektiivisuutta (Maasilta ja Nikunen 20/8). Tässä tarkastelemme suomalaisuutta ja kansallistunnetta sellaisena kuin Halla-aho niitä blogissaan tuottaa. Luemme blogia performatiivisena tekstinä. 
Performatiivisuudella tarkoitamme tekstien kykyä saada aikaan asioita; kirjoittamisen voimaa muokata todellisuutta (Austin 1962; Butler 2006). Lähestymistavassamme performatiivisuus ja Ahmedin affektiteoria yhdistyvät Hutcheonin tekstintutkimukseen ja populistisen retoriikan tutkimukseen. Rajaamme käsittelymme tietyn, Halla-aholle keskeisen teeman eli nationalismin tarkasteluun tekstuaalisella tasolla. Tämä mahdollistaa tarkan ja syväluotaavan lähiluvun, joka kuitenkin kiinnittyy kontekstiinsa affektin performatiivisuuden kautta. Analysoimme blogia kiinnittäen huomiota tekstissä tuotettaviin "meidän" ja "muiden" kategorioihin. Ketkä määritellään suomalaisiksi, ketkä taas kansakuntaan kuulumattomiksi tai suoranaisiksi uhiksi? Voiko nationalistis-populistinen suomalaisuus syntyä positiivisten tunteiden perustalle vai rakentuuko kansakunta viholliskuvien tai kielteiseksi koettujen asioiden vastustamisen varaan?

\section{Nationalismi, banaalius ja viha}

Nationalismi eli kansallistunne tarkoittaa sitä, että ihmiset ymmärtävät itsensä kansallisvaltioon kuuluviksi. Benedict Andersonin (1983) määritelmän mukaan kansakunta on kuitenkin aina kuviteltu yhteisö, jota pitää yhdessä toisilleen tuntemattomiin ihmisiin rakennettu usko tietyn alueellisesti rajatun joukon yhtenäisyydestä. Jaettu kansallisidentiteetti ei synny itsestään, vaan sitä tuotetaan erilaisin keinoin. Nationalismia ylläpidetään toistamalla ymmärrystä "meistä" kansakuntana eri representaatioissa ja byrokraattisissa prosesseissa.

Anderson korostaa kansallisen lehdistön vaikutusta nationalismiin; viestinnän digitalisoituessa sosiaalisella medialla on yhä suurempi merkitys. Michael Billigin (1995) mukaan kansallistunnetta ylläpidetään symbolein ja arkisessa elämässä toistuvin representaatioin, jotka tuottavat kansallista kuulumista. Nationalismia tuotetaan toistamalla ymmärrystä "meistä", kansakunnasta, esimerkiksi sanomalehtien osastojen jaossa kotimaan ja ulkomaiden uutisiin, urheilukilpailuissa, joissa "me" kilpailemme "muita" vastaan, seremoniallisesti esitetyissä kansallislauluissa jne. (Mt.)

Andersonille nationalismi on neutraalia. Kiinnittyessään äärioikeistolaisiin liikkeisiin nationalismi muuttuu. Viime vuosina muun muassa Euroopassa ja Yhdysvalloissa noussut laitaoikeistolainen kansallismielisyys on johtanut rasismin lisääntymiseen. Kun banaali nationalismi (Billig 1995) kiinnittyy muukalaisvihan ja naisvihan kaltaisiin vahingollisiin ideologioihin, se muuntuu joillekin ihmisryhmille vaaralliseksi ja pystyy affektiivisesti mobilisoimaan ihmisiä toimintaan näitä vastaan (Saresma 2020).

Etnonationalismilla tarkoitetaan uskomusta, jonka mukaan kansakunnan perustan muodostavat sen etniset ja muut perustavanlaatuisina pidetyt, usein kuvitellut yhtenäispiirteet, kuten geneettinen perimä. Etnonationalismissa eri etnisiä ja kulttuurisia taustoja omaavat ryhmät ymmärretään lähtökohtaisesti yhteensopimattomiksi. Muut ryhmät suljetaan pois joko suoraan oman ryhmän idealisoinnilla tai toisten ryhmien systemaattisella toiseuttamisella. Perussuomalaiset nuoret ovat herät- 
täneet huomiota mediassa ottamalla kantaa "puhtaan" suomalaisuuden puolesta. Järjestön johtoon kuuluvat henkilöt ovat julkisesti ilmaisseet etnonationalistisia mielipiteitä, joiden mukaan geenit ja perimä ratkaisevat sen, ketkä ovat "oikeita" suomalaisia (Ovaskainen 2019).

Kuvatunlainen oikeistopopulistinen liikehdintä on ilmennyt useissa tapauksissa vainona ja vihapuheena. Myös Suomen poliittisella kentällä vihapuhe on lisääntynyt viime vuosina (Knuutila et al. 2019). Euroopan neuvoston ministerikomitean määritelmän mukaan vihapuhe levittää tai lietsoo etnistä vihaa, ulkomaalaisvastaisuutta tai muuta suvaitsemattomuuteen pohjaavaa vihaa (https://www.poliisi.fi/vihapuhe). Vihapuheen yksiselitteinen määrittely on vaikeaa, mutta usein sen ajatellaan kohdistuvan tiettyyn yksilöön tai ryhmään, joka stigmatisoidaan ja jota vähätellään tai jota vastaan lietsotaan haitallisia tunteita ja toimintaa, sillä tämä ryhmä konstruoidaan oikeutetun vihan kohteeksi (Parekh 20I2: 40-4I; Maussen ja Grillo 20I4: 175). Vihapuhe pyrkii hiljentämään esimerkiksi politiikkaan osallistuvia (Knuutila et al. 2019) ja tällä tavalla rapauttamaan demokratiaa. Vihapuheen ja toiminnan, kuten viharikosten, kausaalinen suhde ymmärrettiin toisen maailmansodan jälkimainingeissa, eikä ymmärrystä kielestä toimintana tai julkisen puheen merkitystä poliittiseen mobilisaatioon voi enää kieltää (Maussen ja Grillo 2014: 178-179).

\section{Scripta: materiaali ja metodi}

Blogit ovat tehokas viestintäkeino. Niiden avulla voi saada julkisuutta aatteilleen ja kerätä kannattajakuntaa. Blogeja hyödynnetään esimerkiksi nationalismin ja maahanmuuttovastaisuuden levittämiseen. Oikeistopopulistit sekä Suomessa että Ruotsissa bloggaavatkin innokkaasti (Pettersson 2017). Halla-ahon Scriptan ohella tunnettujen perussuomalaispoliitikkojen blogeja ovat esimerkiksi puolueen entisen puheenjohtajan Timo Soinin Ploki, jota Laura Parkkinen (2017) on analysoinut uskonnollisen retoriikan näkökulmasta, sekä euroedustaja Laura Huhtasaaren blogi. Blogit ovat selvästi poliittisia: ne viestivät kirjoittajansa poliittista agendaa ja ideologiaa ja pyrkivät retoriikallaan saamaan lukijan puolelleen.

Poliittisia blogeja voi perustaa kuka tahansa. Usein ne sijoittuvat konventionaalisen politiikan kentän ulkopuolelle. Poliittinen riippumattomuus yhdistettynä suoraviivaiseen ja väljästi kontrolloituun käyttöliittymään mahdollistaa perinteistä mediaa vapaamman ilmaisun. Poliittisten puolueiden jäsenet voivat blogeissaan käsitellä asioita tavoilla, jotka eivät muissa yhteyksissä olisi mahdollisia. Bloggaamisen suosioon on vaikuttanut blogien historiaa tutkineen Kristin Wolfen (2014: 8-9) mukaan blogialustojen helppokäyttöisyys ja avoimuus. Blogit pystyvät tarjoamaan yleisölle materiaalia nopeudella, johon perinteisemmät ja hitaammat median ja viestinnän muodot eivät pysty (mt.: I0).

Halla-ahon blogi sai nopeasti näkyvyyttä ja vaikutusvaltaa. Scripta - Kirjoituksia uppoavasta lännestä avattiin vuonna 2005. Blogiin integroitiin kaksikymmentä Halla-ahon kotisivuillaan vuosina 2003-2005 julkaisemaa 
kirjoitusta. Blogin kävijämäärä kasvoi nopeasti, ja Halla-ahon omien statistiikkojen mukaan blogin kävijämäärä kasvoi vuoden 2005 aikana 1399 vierailusta 5968 vierailuun kuukaudessa. Vuoden 2006 helmi-marraskuun kävijöiden kuukausittainen keskiarvo oli jo lähempänä kolmeakymmentätuhatta. (Halla-aho 2006a.) Blogikirjoituksessaan "Sivuston statistiikkaa siitä kiinnostuneille” Halla-aho (2006a) pohtii kävijämäärän kasvua. Mediakohua aiheuttaneiden tekstien lisäksi Halla-aho mainitsee bloginsa vieraskirjan selittävän sivuston kävijämäärän lisääntymistä. Vieraskirjasta tuli nopeasti vilkas ja suosittu viestintäalusta, josta muotoutui vuonna 2008 nykyisin Hommaforumina tunnettu keskustelusivusto.

Scriptaan sisältyy kokonaisuudessaan yli I 500 sivua. Blogi sisältää aihepiireiltään monenlaisia tekstejä, jotka on julkaistu 17 vuoden aikana. Valtava aineisto oli rajattava siten, että sen laadullinen analyysi oli mahdollista. Koska tutkimuskysymyksemme liittyvät Halla-ahon tapaan käsitellä maahanmuuttoa ja kansallismielisyyttä sekä sitä, kuinka hän hyödyntää negatiivisia affekteja, rajasimme tarkastelun näihin teemoihin. Rajaus tehtiin käyttämällä tiettyjä hakusanoja, jotka valittiin aiemman aihepiirin tietämyksemme ja blogin kursorisen luennan perusteella. Luimme satunnaisia blogitekstejä ja poimimme niistä Halla-ahon yleisesti käyttämiä termejä, jotka olivat tutkimuskysymyksiemme kannalta oleellisia. Tällaisia olivat "Suomi", "suomalaisuus", "kansa", "kansallismielisyys", "kansallismielinen", "monikultturismi", "maahanmuutto", "suvaitsevaisto". Alustavan luennan jälkeen teimme mainittujen sanojen haut koko blogitekstikorpukseen. Tällä tavalla korpuksesta valikoituneiden tekstien raaka-analyysin yhteydessä löytyi uusia, Halla-ahon teksteille ominaisempia termejä, kuten "suvakki", "monikulttuuri-ideologia", "eliitti" tai "vihervasemmisto".

Varsinaisen tutkimusaineiston keruu toteutettiin vaiheittain analysoitavaa materiaalia rajaamalla ja hyödyntämällä kullakin kierroksella sitä uutta tietoa, jota saimme perehtyessämme tutkimusaineistoksi valittuihin teksteihin tarkemmin. Etenemällä aineistonkeruussa porrastetusti ja hienosäätämällä korpuksen rajaamisessa käyttämiämme muuttujia eli tarkentamalla hakusanoja pystyimme luomaan tekstiin laajemman katsauksen kuin mikä olisi ollut mahdollista etukäteen tarkasti rajatuilla hakusanoilla. Otimme huomioon myös historiallisen kehityksen: 17 vuoden aikana kieli itsessään muuttuu. Muutos on erityisen tyypillistä populistiselle retoriikalle, joka perustuu kielelliseen temppuiluun; lisäksi Halla-aho on tunnettu neologismien eli uudissanojen kehittäjä. (Saresma 2017b; Tuusvuori 2017.)

Metodisesti karkeasta yhä hienovaraisempaan sisällönanalyysiin edeten päädyimme vaiheittain 1500 sivun tekstikorpusta hakusanojen avulla karsien tilanteeseen, jossa meillä oli enää alle sata blogikirjoitusta. Näistä tarkempaan analyysiin valittiin lopulta 21 tekstiä, joissa käsiteltiin nationalismia, maahanmuuttoa ja monikulttuurisuutta, ja jotka muodostavat artikkelimme pohjan. Samaan tapaan on tutkinut Hommaforumia Leena Vänni (2009), jonka aineisto muodostui kahden keskustelualueen viesteistä kootusta korpuksesta. Hänkin tarkasteli kvalitatiivisesti korpuksesta esiin nostamiaan usein esiintyviä sanoja, joiden jälkeen tutki, mitä sanoilla tarkoitetaan ja millaisessa yhteydessä niitä käytetään. 
Luemme Halla-ahon blogia retoris-performatiivisesti (Palonen ja Saresma 2017) eli kiinnitämme huomiota tekstin retoriikkaan ja siihen, mitä se saa aikaan lukijoissaan. Keinoinamme hyödynnämme kriittistä diskurssianalyysia (CDA), jossa kiinnitämme huomiota tekstissä tuotettaviin valta-asemiin (van Dijk 1993), ja retorista analyysia. Käymme lähilukien läpi Halla-ahon blogissaan käyttämiä tyylikeinoja. Tarkastelemme esimerkkien kautta blogin affektiivista ilmaisua ja analysoimme siinä käytettyjä tekstuaalisia keinoja.

Siirrymme nyt käsittelemään blogia tekstinä. Tarkastelemme kansallismielisyyttä blogin läpikäyvänä teemana ja sitä, minkälaista nationalismia Halla-aho performoi. Tämän jälkeen tarkastelemme blogin tyyliä ja erityisesti ironiaa Halla-ahon ilmaisulle keskeisenä keinona. Pohdimme ironian merkitystä Halla-ahon argumentaatiossa sekä sitä, mitä tunteita tekstissä tuotetaan ja miten. Kuvaamme populistiselle retoriikalle ominaista vastakkainasettelua blogin keskeisenä retorisena, affektiivisena strategiana. Lähiluvun lopuksi teemme katsauksen Halla-ahon tapaan lanseerata uudissanoja.

\section{Nationalismi keskeisenä teemana}

Populistisessa viestinnässä toiston merkitys on suuri. Valikoituihin teemoihin keskittyminen on tehokeino, jota Halla-aho hyödyntää blogissaan. Keskeinen, toistuva teema on nationalismi. Se ottaa jopa etnonationalistisia muotoja. Halla-aho ei käsittele etnonationalismia eksplisiittisesti, vaikka se vaikuttaakin taustalla. Hän viittaa blogissaan vain harvoin suoraan esimerkiksi "rotuun" tai biologiaan. Sen sijaan hän keskittyy toisten ihmisryhmien kulttuuristen erojen korostamiseen. Erot toimivat hänelle ulossulkemisen mekanismeina. Jaettuun etniseen, kielelliseen ja kulttuuriseen perimään pohjautuva käsitys kansallisesta suomalaisuudesta kehystää Halla-ahon koko ajatusmaailmaa, ja se on oleellinen myös muiden blogissa käsiteltyjen teemojen kannalta.

Halla-ahon määritelmän mukaan kansat rajautuvat omiksi suljetuiksi kokonaisuuksikseen niille erityisten geneettisten, lingvististen ja kulttuuristen yhteistekijöiden perusteella (Halla-aho 2007a). Määritelmä on geneerinen ja selkeä, mutta Halla-aho ei esimerkiksi Suomen kansasta puhuessaan halua tarkentaa, mitä nämä yhteiset tekijät ovat, kuten hän itsekin huomauttaa tekstissään "Tilastoista ja etnopositiivisuudesta":

\footnotetext{
Kuten olen joskus ennenkin kirjoittanut, "suomalaisuuden" kyseenalaistaminen on sofistista kikkailua. Myönnän, että en osaa määritellä "suomalaista". Silti minulla on vahva intuitio, jonka pohjalta tunnistan kyseisen joukon. (Halla-aho 20I la.)
}

Halla-ahon suomalaisuuden määrittely on epäselvä ja mielivaltainen. Perinteisempi kansallisromanttinen ilmaisutyyli, jossa oma kansa nostetaan muiden yläpuolelle, ominaispiirteiltään erityiseksi entiteetiksi, ei kuulu Halla-ahon retoriikkaan, joka pohjautuu pikemminkin negatiivisten tunteiden herättämiseen kuin nationalistiseen paatokseen. Määritellessään suomalaisuuden väljästi Halla-aho loiventaa etnonationalistisen ideologian räikeämpiä puolia. Näin hän pystyy käsittelemään tulenarkoja aiheita antamatta itsestään fanaattista kuvaa. Hän ei vetoa 
suoraan oman etnisyytensä ylivertaisuuteen. Välttäessään "meidän" ryhmän idealisointia Halla-aho pystyy vapaammin kritisoimaan kaikkea tuon ryhmän ulkopuolelle sijoittuvaa.

Suomalaisuus kehystetään pääosin joko selväjärkisyyden tai sinisilmäisyyden kautta. Maalaisjärjen korostaminen suomalaisuutta määrittävänä tekijänä toistuu useissa Halla-ahon teksteissä. Se yhdistetään usein suomalaisten kuviteltuun maltillisuuteen. Tätä piirrettä korostaa esimerkiksi Halla-ahon puheenvuoro Turun Perusnuorten populismipäivillä:

Suomalaiset kavahtavat kaikenlaista hörhöilyä. Tämä on usein ollut hyvä ominaisuus kansanluonteessamme, koska se on suojellut suomalaista yhteiskuntaa erilaisilta hörhöaatteilta, 30-luvulla fasismilta ja 60-70-luvulla sosialismilta. (Halla-aho 20I0a.)

Suomalaisten maltillisuus esitetään ikiaikaisena luonteenpiirteenä, jonka ansiosta yhteiskunta on pysynyt suhteellisen vakaana läpi historian. Hallaaho kuvailee myös tämän päivän Suomea samoin keinoin. Esimerkiksi Halla-aho korostaa, kuinka suomalaisten maahanmuuttoasenteet perustuvat ksenofobian tai muun tunnelatautuneen suhtautumistavan sijaan järkiajatteluun ja kohtuuteen:

\footnotetext{
[- - ] suomalaiset vastustavat sellaista maahanmuuttoa, josta on Suomelle taloudellista ja yhteiskunnallista vahinkoa, sekä sitä, että heidän hyväntahtoisuuttaan ja sinisilmäisyyttään käytetään häikäilemättä hyväksi. Kävisi ilmi, että suomalaisilla ei pääsääntöisesti ole mitään sellaisia maahanmuuttajia vastaan, jotka kotouttavat itse itsensä, ilman yhteiskunnan jatkuvaa interventiota. (Halla-aho 20l0b.)
}

Maahanmuuttoasenteita käsitellään edellä ainoastaan yhteydessä maahanmuuton taloudellisiin kustannuksiin. Näihin asenteisiin liittyvät sosiaaliset ja kulttuuriset tekijät sekä mahdolliset affektiiviset ulottuvuudet sivuutetaan. Suomalaisten suhtautuminen maahanmuuttoon esitetään käytännöllisenä ja ennakkoluuloista vapaana. Tämä rationaalisuuden korostaminen omaksi koetun ryhmän esittämisessä toistuu Halla-ahon teksteissä.

\section{Populistista vastakkainasettelua}

Populismi perustuu vastakkainasettelulle ja jakolinjojen vetämiselle. Keskeinen vastakkainasettelu on kansan ja eliitin välinen. (Palonen ja Saresma 2017; Palonen ja Saresma 2019.) Tätä jakolinjaa Halla-aho tuottaa toistuvasti asettumalla itse muiden maahanmuuttokriitikoiden lailla kansan ja kansakunnan puolustajaksi eliittiä vastaan. Halla-aho kirjoittaa esimerkiksi, että suomalaisten hyväuskoisuutta on manipuloitu systemaattisesti tavalla, joka hyödyttää vain ammattipoliitikkoja ja mediaa. "Poliittinen eliitti" ei ole ainoastaan kansasta vieraantunutta, vaan se suoraan sortaa ja hyväksikäyttää kansaa eli "meitä". Halla-aho syventää vastakkainasettelua kuvaillen koko poliittista ja akateemista kenttää sekä mediaa Suomen "tavallista" kansaa ja kulttuuria vihaavina instituutioina:

Suomessa poliitikot suorastaan kilpailevat siitä, kuka osaa ilkeämmin ja pisteliäämmin halveksia rahvasta, Suomen kansaa, sen kulttuuria ja historiaa. [- - Mitä etäämmällä poliittisen eliitin näkemykset ovat yleisestä mielipiteestä, sen hienompaa ja fiksumpaa. Sama asenne vallitsee myös tiedotusvälineissä ja akateemisessa maailmassa. (Halla-aho 20l0a.) 
Kirjoituksessa "Puhe Perusnuorten populismipäivillä" tämä polarisoinnin logiikka näyttäytyy kiinnostavalla tavalla, kun Halla-aho kuvaa, kuinka suomalaisille tyypillinen maltillisuus on salakavalasti käännetty ajan mittaan poliittiseksi selkärangattomuudeksi. Tähän ovat syyllisiä suomalaiset "konsensuspuolueet" ja media:

\footnotetext{
Ikävä kyllä konsensuspuolueet ovat oppineet käyttämään tätä ominaisuuttamme hyväkseen. Kaikki veneenkeikuttajat ja yhteisesti sovitulta linjalta poikkeajat on median suosiollisella avustuksella leimattu hörhöiksi. (Halla-aho 20IOa.)
}

Tämä asetelma toistuu blogiteksteissä jatkuvasti. Saman tyyppinen herraviha on ominainen muillekin populistipoliitikoille (Palonen ja Saresma 2019). Esimerkiksi perussuomalaisten edellinen puheenjohtaja Timo Soini hyödynsi samaa retoriikkaa omassa blogissaan (Soini 2007; Parkkinen 2017). Populistinen kansan ja eliitin välille luotu vastakkainasettelu kuvataan erityisen räikeästi Halla-ahon tekstissä "Vähän rikollisuudesta vaihteeksi", jossa hän kuvaa eliitin edustajat yhteiskuntarauhaa rikkovina rotupettureina:

\footnotetext{
Todellinen vikapää ei ole afro, joka toteuttaa itseään juuri niin kauan ja paljon kuin koneisto antaa hänen toteuttaa. Todellinen syyllinen, ja legitiimi vihan kohde, on se utopiassa elävä poliittinen eliitti, jolle neekeri on hoivattava reppana ja kiva halinalle ja joka vähät välittää yhteiskuntarauhasta. (Halla-aho 2005a.)
}

Ote on rasistinen ja misogyyninen. Räikeän etnisen haukkumasanan käytön ohella "afrot" kuvataan luonnostaan rikollisina ja kehittymättöminä. Parekhin (20I2: 40-4I) määritelmään tukeutuen tässä voisi olla kyse jopa vihapuheesta: se kohdistuu tiettyyn ihmisryhmään, jota stigmatisoidaan ja jota vastaan lietsotaan haitallisia tunteita ja toimintaa. Eliitti kuvataan katkelmassa korostetun feminiinisenä ja lapsellisena puhumalla "hoivaamisesta" ja "halinalleista". Halla-aho rakentaa kuvaa eliitistä legitiiminä vihan kohteena. Tämä rationalisoitu affektiivinen purkaus kuvaa luodun vastakkainasettelun tavoitetta: kääntää lukijat Halla-ahon kuvaamaa eliittiä vastaan - ja samalla hänen puolelleen. Halla-aho ei juuri mainitse sitä, että hän itse kuuluu akateemiseen eliittiin koulutuksensa perusteella: Soinikin on maisteri, Halla-aho on väitellyt jopa tohtoriksi. Poliittiseen eliittiin sekä Halla-aho että Soini kuuluvat puolueensa toinen toistaan voitokkaampiin vaaleihin vieneinä puheenjohtajina ja euroedustajina, mutta molemmat esittävät itsensä populistisesti kansan miehinä.

Halla-aho kritisoi blogiteksteissään vasemmistolaisia toimijoita. Hän ei kuitenkaan yleensä tarkenna, minkälaisista vasemmistolaisista ryhmistä tai ideologioista on kyse. Oleellista on Halla-ahon pyrkimys kehystãä vasemmistolaisuus kansan edun vastaiseksi. Halla-ahon tapaa kuvata "vasemmistoeliittiä" leimakin enemmän ambivalentti identiteettipolitiikka kuin varsinainen ideologian kritiikki. Joissakin teksteissä vasemmistolaisuuden kuvauksiin lisätään räikeän fantastisia piirteitä, joiden kautta viholliskuvaa luodaan dramaattisin keinoin esimerkiksi tekstistä "Monikultturistinen vallankumous":

\footnotetext{
Marksilainen klikki masinoi retoriikallaan kiljupunkkarit kadulle osoittamaan mieltään, mikä säikäyttää ei-marksilaisen osan poliittisesta eliitistä ja virkakoneistosta kuvittelemaan, että kiljupunkkareiden näkemykset edustavat kansan syvien rivien tuntoja. (Halla-aho 2005b.)
} 
Kiljupunkkarit ovat Halla-ahon visiossa "Marksilaisen klikin” katusotilaita, jotka se voi masinoida tarpeen mukaan manipuloimaan kansan mielipiteitä. Tavallinen kansa kuvataan johdettavissa olevana massana. Halla-aho liittää tekstissään rasismin vastaiset mielipiteet nimenomaan vasemmistolaiseen ideologiaan ja nuorisohuliganismiin ja kuvaa ne lukijalle jonakin, jota tulee lähtökohtaisesti vastustaa.

Halla-ahon eliitin kuvauksissa on tyypillistä myös arkielämästä vieraantuneisuuden korostus. Arjen realiteetit eivät kosketa eliittiä, joka elää loisena tavallisen kansan kustannuksella. Blogikirjoituksessa "Nöyryydestä todellisuuden edessä" Halla-aho kohdistaa tämän kritiikin erityisesti "akateemiseen eliittiin":

\footnotetext{
Ajallemme on tyypillistä tyhmyyden palvonta. Tyhmyyttä ruokkii paitsi [- - ] tosi-tv myös yhteiskuntapoliittinen virtaus, joka palkitsee yksiäänisen hymistelyn "oikeiden" asioiden puolesta ja demonisoi (ja sanktioi) "oikeiden" asioiden kyseenalaistamisen. [- - Akateemisissa piireissä käy ankara kilpailu siitä, kuka on edistyksellisin ja suvaitsevaisin ja kuka osaa saada hysteerisimmän kohtauksen taantumuksellisia ajatuksia kohdatessaan. (Halla-aho 2005c.)
}

Halla-aho on pidäkkeetön älyllisen eliitin kritiikissään: hän kehystää akateemisen eliitin ideologiaa trendinomaiseksi ja kaikesta älyllisestä toiminnasta riippumattomaksi. Näin hän luo yliopistojärjestelmästä kuvan täysin epäakateemisena ja epä-älyllisenä: akateeminen eliitti ei pyri tiedon edistämiseen, vaan tähtää ainoastaan jäsentensä statuksen ylläpitämiseen.

\section{Rationaaliset suomalaiset ja tunteiden vietävät muut}

Halla-aho tuottaa blogissaan aktiivisesti samaa jakoa järkeen ja tunteisiin, joka on määrittänyt länsimaista ajattelua Descartesista saakka. Tunteiden kulttuurisuutta tarkastellessaan Sara Ahmed (20I8: II-13) kuvaa tapaa, jolla järjen nähdään edelleen edustavan sivilisaatiota, tunteiden luonnontilaisuutta. Rationaalisuus liitetään blogissa järjestykseen ja valtaan, tunteet vastaavasti heikkouteen ja kaaokseen. Halla-ahon sukupuolittavan argumentaation kannalta on kätevää, että tämä dualismi liitetään miesten ja naisten sekä kulttuurin ja luonnon kahtiajakoon. Osoitamme seuraavassa, että jaossa on kyse sukupuolen ja "rodun" kategorioiden toisiinsa kytkeytymisestä blogin argumentaatiossa.

Kulttuuri-luonto -dualismi ilmenee Halla-ahon kirjoittaessaan maahanmuuttajista esimerkiksi tekstissä "Kuinka osaamispotentiaalia hyödynnetään" (Halla-aho 2006b), jossa hän kuvaa maahanmuuttajat primitiivisinä ja sivistymättöminä todeten: "[M]aahanmuuttajat eivät osaa muuta kuin kasvattaa kameleita”. Muissa yhteyksissä hän kuvaa maahanmuuttajia ja ei-länsimaisiin kansallisvaltioihin kuulumattomia ryhmiä samalla tavoin barbaarisina puhuen esimerkiksi "maahanmuuttajalaumoista" (Halla-aho 2006c) ja liittäen lisääntyvän maahanmuuton rikollisuuden ja rauhattomuuden kasvuun (Halla-aho 2008).

Miesten ja naisten tai maskuliinisiksi ja feminiinisiksi miellettyjen piirteiden vastakkainasettelu toistuu Halla-ahon kuvatessa maahanmuuttomyönteisiä tahoja. Halla-aho käyttää heistä korostetun paljon 
perinteisesti feminiinisiksi miellettyjä sanoja, kuten 'kiva' tai 'ihana', saaden maahanmuuttomyönteisten ideologiat näyttämään irrationaalisilta (Halla-aho 2006c). Maahanmuuttajamyönteiset tahot kuvataan vaistojensa vietävinä:

\begin{abstract}
Me saamme yhdeksää elätettävää ja asenneongelmaista kohti yhden, josta on jotakin hyötyä. Syy tähän on se, että ne, jotka syyttävät minua ihonväriin ja uskontoon tuijottamisesta, eivät itse näe tulijoissa mitään muuta. Heille tulijan tumma iho ja Allahin palvonta ovat riittävä kriteeri päästää tämä maahan. Koska toiseus on heille fetissi. (Halla-aho 2006d.)
\end{abstract}

Tässä lainauksessa maahanmuuttajiin suopeasti suhtautuvien (naisten) vihjataan tuntevan seksuaalista kiinnostusta tummaihoisia (miehiä) kohtaan. Halla-ahon blogin perusargumentti perustuu maahanmuuttajien toiseuttamiselle ja sukupuolittamiselle. Tuija Saresma (2017a) on analysoinut Halla-ahon blogitekstiä "Monikulttuurisuus ja nainen" (vuodelta 2006), jossa Halla-aho väittää monikulttuurisuuden olevan naisten vika: toisin kuin maahanmuuttoa rohkeasti vastustava miesten enemmistö, naiset - erityisesti "vihervasemmistolaiset maailmanparantajat" - asettuvat "harhautuneen hoivaviettinsä" vallassa puolustamaan maahanmuuttajia, Halla-ahon sanoin "barbaariraiskaajia".

Sukupuolittaminen ja rodullistaminen tuottavat toiseutta. Samalla tavoin kuin kolonialistisessa ajattelussa, jossa muut kuin länsimaiset nähdään infantiileina villeinä, myös tässä oletettu primitiivinen toiseus asetetaan vastakkaiseksi (länsimaiselle) sivilisaatiolle. Sivistystä edustavat järjen hyveet, barbariaa taas eläimellinen, tunteellinen toiseus, joka kuitenkin luonnehtii myös länsimaisia "hyysäreitä".

Halla-aho kuvaa "suvaitsevaista maailmankuvaa" usein uskonnolliseksi ja hän puhuu jopa "monikultturismi-uskonnosta" (Hallaaho 2006e) sijoittaen maahanmuuttomyönteisyyden rationaalisen ajattelun ulkopuolelle ja leimaamalla sen halventaen tunteelliseksi. Maahanmuuttajamyönteiset tahot sijoitetaan rationaalisen toimijuuden ulkopuolelle tietoisilla ja systemaattisilla kielellisillä valinnoilla.

Järki-tunne -vastakkainasettelu ilmenee blogissa myös räikeämmillä tavoilla esimerkiksi Halla-ahon käsitellessä väkivaltarikoksia. Hän kuvaa maahanmuuttajien tekemää väkivaltaa raakana, mielivaltaisena ja barbaarisena, kun taas suomalaisen kantaväestön väkivalta kuvataan ymmärrettävänä ja vähemmän haitallisena:

\footnotetext{
Paitsi että maahanmuuttajien harrastama väkivalta on erittäin tavallista ja lisää yhteiskunnan absoluuttista vaarallisuutta, se eroaa kotoperäisestä mätkimisestä laadullisesti useassa suhteessa: a) Tekijät ovat selvinpäin; b) Väkivalta on silmitöntä, tekijöiden pyrkimyksenä on vahingoittaa, rampauttaa ja tappaa eikä esimerkiksi puolustaa humalaista kunniaansa; c) Väkivalta kohdistuu keneen tahansa vastaantulijaan, mistä seuraa, että kaikki ovat vaaravyöhykkeessä, eikä tavallinen kansalainen voi millään keinolla pienentää itseensä kohdistuvaa riskiä. (Halla-aho 2007b.)
}

Halla-aho kategorisoi suomalaisen väkivallan järjestyksen piiriin luoden samalla "ei-suomalaisista" muukalaisvastaiselle ajattelulle tyypillistä toiseuttavaa kuvaa. Hän lietsoo pelkoa puhumalla esimerkiksi raiskaajista määrittelemällä nämä lähes aina lisämääreillä', kuten ”kenialai-

\footnotetext{
' Sana 'raiskaaja' esiintyy Halla-ahon blogissa tässä perusmuodossa 30 kertaa. Näistä ainakin I8:n kohdalla raiskaajaa luonnehdittiin jollakin "ei-suomalaiseen" viittaavalla määreellä.
} 
nen", "somali", "muslimi", "ulkomaalainen", "ulkomaalaisen värinen", "kolmannen maailman" tai "afrikkalainen" ja sukupuolittaen samalla maahanmuuttajat lähes poikkeuksetta miehiksi (Saresma 20I8). Tämä kuvaus uusintaa rasismille tyypillistä näkemystä, jossa omaksi koettu ryhmä kuuluu aina arvohierarkian huipulle (Wimmer 2002: 202), silloinkin, kun käsiteltävänä on moraalisesti kyseenalainen väkivalta.

Halla-aho esittää "meidät" maahanmuuttoon kriittisesti suhtautuvat rationaalisina järki-ihmisinä ja "muut" tunteiden vallassa kaoottisesti toimivina. Samanaikaisesti järjen ja tunteiden vastakkaisuutta syö se, että blogin ilmaisu perustuu pohjimmiltaan affektien herättämiselle. Tunteisiin vedotaan, lukijaa provosoidaan ja ärsytetään tarkoituksella. Vaikka Halla-ahon tyyliä voi pitää tunnekylmänä, se ei ole tunteetonta. Tunnekylmyys on itsessään affektiivista. Tunteiden tai niiden ilmaisun puuttuminen voi aiheuttaa vahvan affektiivisen reaktion. Tunteeton asettuu ikään kuin katsomaan tapahtumia yläpuolelta, ne eivät kosketa häntä, vaan hänestä tulee tapahtumien "neutraali" tulkki. Tunteettomuus on myös ilmaus siitä, että toinen ei ole kelvollinen tunteiden kohteeksi. Sara Ahmed (2018: I3) on todennut, että kovuus ei ole tunteiden poissaoloa vaan toisenlaista suhtautumista toisiin. Kovuudella ja näennäisellä tunteettomuudella pyritään itsen ylentämiseen. Juuri näin toimii Halla-ahon blogi. Sen retoriikka on rauhallista ja tyyli etäännyttävän ironista, eikä se ole pintatasollaan tunnepitoista. Siitä huolimatta teksti voi herättää affekteja.

Politiikantutkijat ovat alkaneet kiinnittää huomiota tunteiden ja affektien merkitykseen konfliktien dynamiikassa: kärjistyneissä konflikteissa, kuten sodissa, viha "toisten" ryhmää kohtaan kietoutuu erottamattomasti yhteen omaa ryhmää kohtaan tunnetun rakkauden kanssa (Hoggett ja Thompson 20I2). Myös Sara Ahmed on kirjoittanut vihasta, jonka "lähteiksi" teksteissä kuvattavat "toiset" - esimerkiksi maahanmuuttajat - asetetaan. Viha ja muut tunteet ovat Ahmedin (2018: 19-20) mukaan kulttuurisia käytäntöjä: ne koetaan suhteessa toisiin ja ne suuntautuvat kohti toisia. Vihan ympärille syntyy verkossa tunneyhteisöjä, jollaiseksi Halla-ahon blogin ympärille syntyneen yhteisöllisyyden voi tulkita. Viha ei välttämättä ole tällaisten verkkoyhteisöjen alkuperäinen käyttövoima, vaan se voi olla retorisesti nostatettu tunne, joksi vähemmän hyväksytyt tunteet tai muut kokemukset, esimerkiksi epävarmuus, huolestuneisuus tai ahdistuneisuus pyritään kanavoimaan (Vainikka 2019; Saresma 2020).

\section{Ironia ja iva tyylikeinoina}

Halla-aho on tullut tunnetuksi ironisesta tyylistään. Kielellisenä tyylinä ja yleisenä sävynä näyttäytyvä "ironian politiikka" on Kaarina Nikusen (20I5) mukaan ominainen maahanmuuttovastaiselle liikkeelle. Se ilmenee kolmella tavalla: ensinnäkin rationaalisuuden ja naiiviuden vastakkainasetteluna, jota kuvasimme edellä, toiseksi edellä osoittamaamme tapaan ihmisryhmien vastakkainasetteluna ja jaettuna affektiivisuutena, jota Halla-aho harjoittaa luomalla pelon ja kaunan ilmapiiriä, ja kolman- 
neksi yksisuuntaisena poliittisena kommunikaationa (mt.: 2I). Viimeksi mainittua tarkastelemme seuraavassa. Osoitamme, että Halla-ahon näennäisesti dialoginen blogi perustuu kommunikaatioon, jossa kirjoittaja kommentoi käsittelemiään asioita ja toimijoita alentuvasti, ylemmyydentuntoisesta positiosta käsin.

Ironiaa pidetään Linda Hutcheonin (1994) mukaan rationaalisena ja ei-affektiivisena, vaikka se itse asiassa aiheuttaa affektiivista epämukavuutta: se "kieltää varmuuden, pilkkaa, tekee naurettavaksi, sulkee ulos, nolostuttaa, nöyryyttää" (mt., I4; Nikunen 2015: 23). Ironia on määritelmällisesti sitä, että sanotaan yhtä, mutta tarkoitetaan toista; kun merkitsijä irrotetaan tällä tavalla referentistä, syntyy epävarmuutta merkityksestä. Ironia perustuu kärjistyksille ja siihen liittyy affektiivista voimaa, jota ei voi erottaa sen poliittisuudesta. (Hutcheon 1994: 14.) Nikunen osoittaa artikkelissaan, miten Hutcheonin ironian elementit - kriittinen näkökulma, semanttinen kompleksisuus, intentio ja kohdentaminen sekä kontekstuaalinen kehystäminen ja diskursiiviset yhteisöt - toimivat maahanmuuttovastaisen liikkeen argumentaatiossa. Ironiaa hyödynnetään affektiivisena käytäntönä, joka vie poliittisia näkemyksiä äärimmilleen ja vahvistaa yhteisöä. Sama toimintatapa luonnehtii Halla-ahon blogikirjoituksia, jotka ovat keskeisessä roolissa suomalaisessa maahanmuuttovastaisessa keskustelussa.

Halla-aho esittää toistuvasti tahallisia väärinluentoja tulkitsemistaan teksteistä. Esimerkiksi lukiessaan Helsingin yliopiston ylioppilaskunnan Toiminnallista tasa-arvosuunnitelmaa vuosille 2007-2008 blogitekstissään "Moninaisuusmyönteinen yliopisto" (I 0.I I.2006) hän lainaa useita katkelmia, joiden viestin sitten kyseenalaistaa. Halla-aho asettuu paremmin tietäjän ylempään positioon, besserwisseriksi, kuten "mestarille" sopii. Blogiteksteille on ominaista myös tarkasteltujen ilmiöiden ja ihmisten naurunalaiseksi tekeminen. Halla-ahon ironia on usein ilkeilyä, kuten seuraavassa kommentissa HYY:n tasa-arvosuunnitelmaan, jossa ironian kärki kohdistuu ns. suvaitsevaistoon:

Dziizaz. Minun ON PÄÄSTÄVÄ katsomaan elämyksellistä moninaisuuskoulutusta, johon sisältyy draamatyöskentelyä. (Halla-aho 2006f.)

Lausahdus on tietenkin parodinen. Linda Hutcheon (1985) määrittelee parodian toistoksi, joka toistaessaan ottaa kriittistä etäisyyttä toistettavaan tekstiin. Halla-aho lainaa melkein sanasta sanaan kommentoimaansa tekstiä, mutta merkitsee omaa etäisyyttään siihen käyttämällä puhekielistä sanaa "Dziizaz" ja isoja kirjaimia, jotka osoittavat, että kirjoittaja on - ironisesti - aivan päinvastaista mieltä kuin mitä hän väittää olevansa.

Tyylillisesti Halla-ahon ironiaa voi lukea provokaationa. Hän pistelee vastustajiaan kvasiloogisten päättelyketjujen avulla ja käy heikompiensa kimppuun. Ivan kohteena ovat marginaaliryhmien, kuten maahanmuuttajien ohella esimerkiksi nuoret, kuten edellä mainitussa HYY:n tasa-arvostrategiassa. Samalla tavalla tapahtuu, kun Halla-aho käy yhdeksäsluokkalaisen Perttu Partasen julkaistun kirjoituksen "Miksi rasisti on aina väärässä" kimppuun blogitekstissään "Suvaitsevaisia nyrjähdyksiä". Hän toteaa, ettei ole "kaunista eikä korrektia raadella 35 ikävuoden elä- 
mänkokemuksella ja ylemmän korkeakoulututkinnon arvovallalla [- - ] koulupojan tekstiä" - mutta tekee sen silti (Halla-aho 2007c).

Muiden kirjoituksista saivarteleminen voi olla harkittu retorinen keino, jonka tarkoitus on yksinkertaistaa ja kenties väsyttää vastustajaksi ajateltu lukija. Tyyli voi pitkästyttää myös mestarin seuraajia. Esimerkki viisastelusta on noin I4 sivun mittainen kirjoitus "Katsaus julkilausuman kirvoittamiin kommentteihin" (I I.6.20 I I), jossa Halla-aho (20I lb) käy läpi perussuomalaisten "rasisminvastaisen" julkilausuman vastaanottoa (Perussuomalaisten eduskuntaryhmä 20I I). Julkilausumaa vaadittiin puolueelta kansanedustaja Teuvo Hakkaraisen käytettyä julkisesti loukkaavaa $\mathrm{n}[--$ ]ukko-sanaa. Halla-aho tovereineen laati lausuman, mutta siinä väännettiin ja käännettiin viesti siten, että rasismista ei irtisanouduttu, vaan ajettiin tasa-arvotyön ja maahanmuuttajien kotiuttamisen vastaista agendaa. Tämän julkilausuman vastaanottoa Halla-aho kommentoi blogissaan näennäisen dialoginomaisesti, käyden keskustelua julkilausumaa arvostelleiden kanssa, mutta tosiasiassa kommentoiden näitä pisteliäästi ja tekemällä heistä naurunalaisia.

Toisissa yhteyksissä Halla-aho esittää yliampuvia kärjistyksiä näennäisen rationaalisesti perustellen. Esimerkiksi bloggauksessaan "Sosiaalidemokratiasta ja islamismista" Halla-aho esittää salaliittoteoriaa muistuttavan päätelmäketjun, joka rakentuu väitteelle vasemmiston ja maahanmuuttajien salajuonesta suomalaisen poliittisen kentän vääristämiseksi:

\footnotetext{
Se, että "liberaali vasemmisto" suvaitsee islamia ja sen lieveilmiöitä, selittyy toki osittain puhtaalla ja perinteisellä kukkahattuilulla ja ksenofilisellä sokeudella, mutta kyse on myös rahasta ja vallasta. Suorittavan työn kadotessa Euroopasta ja loppujenkin duunareiden siirtyessä äänestämään kansallista etua korostavia "populistipuolueita" vasemmisto tarvitsee uusia äänestäjiä. (Halla-aho 20I3.)
}

Kvasilooginen argumentaatio perustuu uhkakuvien lietsontaan. Hallaahon ironia tuottaa kylmän rationaalisen vaikutelman, mutta samalla teksti vaikuttaa affektiivisesti. Edellinen esimerkki ilmentää tapaa, jolla Halla-aho hyödyntää ironialle tyypillisten kaksoisyleisöjen ja kaksoispuheen retoriikkaa: kannattajille uskotellaan, että vääryyksiä Suomen kansaa kohtaan tapahtuu, ja samalla vastustajiksi koettuja provosoidaan affektiivisiin reaktioihin pintatasoltaan kylmän toteavassa tekstissä.

Linda Hutcheonin (1985) mukaan kaksoisyleisöjen olemassaolo on tarpeellista ironialle. Ironia on mahdollista vain, jos jotkut ymmärtävät sen ja toiset eivät. Halla-ahon blogien ironia on varsin ilmeistä, eikä se erottele lukijoita samalla tavalla kuin ironia kaunokirjallisuuden tyylikeinona. Ironian taakse on kuitenkin mahdollista piiloutua ja välttää vastuuta sanomisistaan, sanoa "vain piloillaan". Ironia on keino välttää vastuuta ja jättää se kuulijalle - provosoituminen on tämän ongelma, ei kirjoittajan. Tätä taktiikkaa käyttää myös kansallismielisyydestään tunnettu esseisti Timo Hännikäinen. (Saresma 2016.)

Kaksoisyleisöt ja Vaarakallion (2017) analysoima kaksoispuhe toimivat Halla-ahon eduksi. Samalla kun Halla-aho provosoi vastustajiaan hänen kirjoituksensa yhdistävät samanmielisiä ja rakentavat oikeistopopulistista tunneyhteisöä ironian avulla. Kirjoittajana Halla-aho kuiten- 
kin ottaa etäisyyttä lukijoistaan, myötämielisistäkin. Scriptan kaikkivoipa viisastelevuus pyrkii hiljentämään vastustajat, mutta ei jätä kannattajillekaan kuin äänettömän myötäilyn mahdollisuuden. Ainoa, mihin kannattajakunta voi osallistua, on innolla levittää mestarinsa kehittämiä uudissanoja maahanmuuttovastaisen agendan levittämiseksi kuin profeetat jumalansa sanaa. Mielleyhtymä uskonnollisiin johtajiin, joiden tekstejä seuraajat tulkitsevat ja joiden oppeja noudattavat, ei ole kaukaa haettu siksikään, että asettuessaan etäisen tyylinsä taakse Halla-aho nostaa itsensä arvostelun yläpuolelle.

\section{Uudissanojen performatiivisuus}

Populismille itsessään tyhjänä ideologiana on ominaista ottaa käyttöön ja "vallata" käsitteitä sekä antaa niille uusia merkityksiä. Esimerkiksi sananvapauden käsite on politisoitunut populistien käytössä: uudiskäytössä sananvapauden nimissä levitetään äärioikeistolaista, muukalaisvihamielistä propagandaa. Populismille tyypillisesti maahanmuuttovastaiset "nuivat" ovat lanseeranneet "käänteisrasismin" ja "matun" kaltaisia uudissanoja. (Saresma 2017b.)

Scriptan retorisista keinoista tarkastelemme lopuksi Halla-ahon tapaa tuottaa uudissanoja, jotka tukevat hänen omaa agendaansa eli maahanmuuttovastaisuutta. Hän on onnistunut syöttämään useita tällaisia päällisin puolin neutraaleilta näyttäviä neologismeja medialle, joka on omaksunut ne lähes kritiikittä. Halla-ahon uudissana "maahanmuuttokriittinen" lanseerattiin muukalaisvastaisilla foorumeilla. Halla-ahon blogissa se esiintyy ensimmäistä kertaa vuonna 2006 (Halla-aho 2006g). Sillä tarkoitettiin henkilöitä, jotka suhtautuivat maahanmuuttoon lähtökohtaisesti kielteisesti. Muukalaisvihamielisyydestä tehtiin eufemismin avulla salonkikelpoista - tokihan "kriittisyys" kuulostaa analyyttisemmalta kuin "kielteisyys". Maahanmuuttokriittisyys on omaksuttu yleiskieleen ikään kuin neutraalina sanana. Se on kuitenkin itsessään affektiivinen tihentymä, johon tiivistyvät "maahanmuuttajia kohtaan tunnettu epäluulo ja pelko, puhe islamisaatiosta ja länsimaiden tuhosta sekä turvapaikanhakijoiden hädän kyseenalaistaminen”. (Saresma 20I7b;Tuusvuori 20I7.)

Samantyyppinen yleiseen käyttöön levinnyt uudissana, jonka juuret juontavat Halla-ahon blogiteksteihin, on "suvaitsevaiston" käsite, johon nykyisin törmää useammin muodossa "suvakki". Suvaitsevaistotermi on suhteellisen yksiselitteinen, ja sen ensisijainen tarkoitus on mielivaltaisesti niputtaa Halla-ahon kanssa eri mieltä olevat tahot yhden vähättelevän termin alle. Siitä ei ole tullut samalla tavoin salonkikelpoista kuin "maahanmuuttokriittisestä", mutta sitäkin käytetään yleisesti. Samankaltainen pejoratiivinen sana "vihervasemmisto" sen sijaan kuultiin jopa pääministeri Sipilän suusta (Iltalehti 2018). "Väestönvaihto" puolestaan on uuskieltä, jonka taustalla on äärioikeiston salaliittoteoreettinen uskomus (Torvinen 2019). Halla-ahon blogissa väestönvaihto esiintyy käsitteenä ensimmäistä kertaa jo tekstissä "Demografisista asioista ja muista", jossa termin merkitys myös kuvataan varsin yksiselitteisesti ja dramaattisesti: 
Se, mitä länsi-Euroopassa on tapahtumassa, ei ole länsimaalaisen yhteiskunnan maustuminen rikastuttavilla elementeillä vaan yksinkertaisesti väestönvaihto. Eurooppalainen väestö korvautuu afrikkalaisella ja aasialaisella. (Halla-aho 2005d.)

Väestönvaihto-termi kuvaa äärioikeiston pelkoja kasvavan maahanmuuton seurauksista, ja se kytkeytyy "etnisen puhtauden" menetyksen pelkoon ja siihen liittyvään ahdistukseen. Termi kuulostaa, useiden muiden vastaavien uudissanojen lailla, pintatasolla suhteellisen neutraalilta eikä välttämättä herätä suuria tunteita. Termiä kuitenkin käytetään valkoisten kansanmurhalla pelottelevissa salaliittoteorioissa. Termin rinnalle on myöhemmin kehittynyt "matalan intensiteetin kansanmurhan" käsite, joka samaan tyyliin kuvaa oletettua uhkaa valkoisen kansan systemaattisesta sorrosta ja hävittämisestä. (Hommaforum 20I8.) Molempien termien taustalla on kokemus epäoikeudenmukaisuudesta, siitä että jotain meille ehdottomasti kuuluvaa - kansakunta, valkoinen Suomi - ollaan ottamassa pois. Loukatuksi tulemisen tunne on vahva keino mobilisoida kannattajakuntaa affektiivisesti.

Väestönvaihdosta ja matalan intensiteetin kansanmurhasta puhutaan käytännössä ainoastaan niissä tapauksissa, joissa valkoiset koetaan uhreina. Termiä on alettu käyttää lietsomaan pelkoa ja luomaan uhkakuvia eurooppalaisen "liian sallivan" maahanmuuttopolitiikan seurauksista. Termien leviävyydestä ja salonkikelpoistuneisuudesta kertoo, että muun muassa perussuomalaisten ensimmäinen varapuheenjohtaja Riikka Purra, puoluesihteeri Simo Grönroos sekä perussuomalaisten kansanedustaja Jani Mäkelä ovat kukin äskettäin käyttäneet julkisesti väestönvaihto-käsitettä (Uusi Suomi 2019).

\section{Lopuksi}

Empiirisen systemaattisen luentamme pohjalta esitämme, että ulossulkeva nationalismi on Halla-ahon blogin keskeinen teema. Suomalainen kansakunta esitetään Scriptassa sukupuuton partaalla olevana, uhattuna ja heikkona. Halla-ahon performoima kuviteltu yhteisö kytkeytyy abstrakteihin ideoihin kuten "suomalaisuuteen" ja "kansakuntaan", mutta samalla kansallismielisyys on hyvinkin konkreettista esimerkiksi niissä teoissa, joissa "meiksi" määritellyt saadaan mobilisoitua "kansallismieliseen" toimintaan, esimerkiksi katupartioihin, ja kansakunnan toisiksi määritellyt inmiset joutuvat kokemaan uhkaa ja tulevat jopa karkotetuksi Suomesta.

Blogin lähiluvun perusteella tekstien voima perustuu Halla-ahon kykyyn rakentaa affektiivisesti "meitä" suomalaisia ja sille vastakkaisena ryhmänä "meisyyttä" uhkaavia toisia. Meidän ja muiden väliset erot ja ristiriidat kuvataan blogissa usein äärimmäisin keinoin, toistamalla räikeitä ja polarisoivia vastakkainasetteluja ja kuvaamalla haavoittuvia ryhmiä ja poliittisia vastustajia tavoilla, jotka herättävät lukijoissa vahvoja tunnereaktioita.

Hutcheonin kahden yleisön politiikan ja Vaarakallion kaksoispuheen käsitteen avulla on mahdollista analysoida ja selittää blogin suosiota. Halla-ahon keinot levittää kansallismielisiä arvoja hybridissä media- 
systeemissä ovat monella tavoin systemaattisia. Samat retoriset keinot ja teemat toistuvat blogitekstistä toiseen, mutta ne esiintyvät myös haastatteluissa ja tweeteissä. Blogissa vastustajat esitetään ivalliseen sävyyn ja arveluttavassa valossa. Kannattajien kesken taas luodaan affektiivista, pelolle ja vihalle ja toisen uhalle rakentuvaa kollektiivista "meisyyden" tunnetta. Halla-ahon ympärille rakentuu affektiivinen yhteisö, joka perustuu toisten provosoimiselle. Kaksoisstrategia toimii: samoilla retorisilla keinoilla yhdistetään omia ja provosoidaan "muita".

Halla-aho on vaikutusvaltainen, sillä hän hallitsee populistisen houkuttelun logiikan ja pystyy affektiivisesti mobilisoimaan ihmisiä. Hän on myös onnistunut lanseeraamaan uusia käsitteitä, jotka ovat vaikuttaneet viime vuosien poliittiseen keskusteluun. Scriptassa konkretisoituvat nationalismin tavat mobilisoida ihmisiä affektiivisesti erityisesti pelkoa ja vihaa lietsomalla. Samoin tulevat näkyviksi ne mekanismit, joilla tietyt ryhmät saavat kuulua kansakuntaan, kun taas toiset suljetaan sen ulkopuolelle. Pohjimmiltaan Scriptassa performoidaan valkoista kansallista identiteettiä.

Halla-aho esittää itsensä ja nationalisminsa ytimen eli suljetun valkoisen kansallisvaltion rationaalisena vaihtoehtona: kaikki muut, hänen vastustajansa ja avoimemman rajapolitiikan tai inhimillisen maahanmuuton kannattajat, kuvataan irrationaalisina ja tunteiden vietävinä. Vastakkaiset mielipiteet tehdään naurunalaisiksi ja vastustajat maalataan epäinhimillisiksi. Kielteisiin tunteisiin, kuten vihaan ja pelkoon, vetoaminen on tehokasta, vaikka näennäisesti lukijan vakuuttaminen tapahtuu järkisyihin vetoamalla.

Scripta perustuu ironialle tyylikeinona. Tunteita ei tekstin pintatasolla juuri käsitellä. Affektit ovat kuitenkin vahvasti mukana Halla-ahon sisällyttämisen ja ulossulkemisen politiikassa ja hänen näennäisrationaalisessa argumentaatiossaan. Blogin tyylikeinoina ironia ja sarkasmi provosoivat vastakarvaan lukijoita, mutta yhdistävät samalla tavalla ajattelevia. Ironian tuottama affektiivinen sävy linkittyy kielteisiin tunteisiin, kuten kaunaan ja vihaan, joita edellä lainatuissa esimerkeissä lietsotaan esimerkiksi esittämällä maahanmuuttajat ja "suvaitsevaisto" aina epäilyttävässä valossa. Ironiaa ja nokkeluuksia käytetään myös pehmentämään herätettyjä tunteita sekä ainakin näennäisesti lieventämään julmia syytöksiä ja vaateita. Samalla kun Halla-aho provosoi vastustajiaan, blogin ympärille rakentuu oikeistopopulistinen tunneyhteisö.

Blogin sanoma Suomea uhkaavista "matuista", "väestönvaihdosta" ja "pigmenttilisästä" on kaukana positiiviseksi mielletystä kansallisromanttisesta isänmaanrakkaudesta. Halla-ahon blogiteksteistä välittyvä kansallismielisyys on muukalaisvihaa tihkuvaa nurkkakuntaista nationalismia, samaa laitaoikeistolaisuutta, jota nyt esiintyy eri puolilla Eurooppaa. Suomalaisuus ei ole Halla-ahon blogin nationalismissa rakas asia tai ylpeydenaihe, vaan kansallismielisyys aiheuttaa pikemminkin ahdistusta. Suomalaisuus on jotakin, jonka eteen joutuu taistelemaan. Aseiksi on valittu ironia ja ehdoton kansakuntaan kuulumattomien ulossulkeminen. Jos kansallistunne on rakkautta omaa kansakuntaa kohtaan, blogissa performoitava (ääri)nationalistinen rakkaus ei ole pyyteetöntä. 
Päinvastoin, se on investointi, jonka tulee tuottaa voittoa tai vähintäänkin vastavuoroista hyvää. Samalla isänmaanrakkaus mahdollistaa myös väkevän loukatuksi tulemisen tunteen (Ahmed 2018:9-10).

Nationalistisen viestin levittämisessä eri yleisöille suunnattu kaksoispuhe mahdollistaa rasismin naamioimisen: seuraajat ymmärtävät viestin, vaikka pintatasolla ei sanota mitään väärää. Tätä koodattua puhetta osaavat lukea vain ne, jotka tietävät, mikä sanoma taustalla on. Maussen ja Grillo (20I4: 180) kutsuvat tätä välilliseksi rasismiksi (racism by proxy). Halla-aho käyttääkin viestinsä levittämiseen samoja keinoja kuin äärioikeisto läpi Euroopan, sillä nationalistinen oikeistopopulismi on paradoksaalisesti transnationaalista (Palonen ja Saresma 2019). Viestit ja retoriset keinot kiertävät oikeistopopulistien keskusteluissa ja suodattuvat myös Halla-ahon blogiin siinä määrin, että voidaan puhua "transnationaalista intertekstuaalisuudesta" (Maussen ja Grillo 20।4: 183).

Halla-ahon affektiivinen investointi kansallismieliseen isänmaallisuuteen on tuottanut hänelle aseman puolueen johtajana ja puolueen kannatuksen nousun suurimpien joukkoon. Loukatuksi tulemisen tunne puolestaan sallii pisteliäisyyden ja valkoisen kansakunnan puolustamisen kvasiloogisin argumentein. Pitkällä aikavälillä kirjoitetun Scripta-blogin systemaattinen analyysi osoittaa, että Halla-ahon vihapuheeksikin tulkittavissa oleva argumentaatio on kehittynyt ajan saatossa. Samoin käy selväksi, että blogissa on pitkin matkaa lietsottu kiihkomielistä nationalismia, joka on tähdännyt "toisten" ulossulkemiseen sekä kansakunnasta että poliittisesta keskustelusta.

\section{LÄHTEET}

Ahmed, Sara 2018/2004: Tunteiden kulttuuripolitiikka. Alkuteos Cultural Politics of Emotion. Suom. Elina Halttunen-Riikonen. Tampere: niin \& näin.

Anderson, Benedict 2007/I983: Kuvitellut yhteisöt. Nationalismin alkuperän ja leviämisen tarkastelua. Alkuteos Imagined Communities: Reflections on the Origin and Spread of Nationalism. Suom. Joel Kuortti.Tampere: Vastapaino.

Austin, John L. 1962: How to Do Things with Words. Oxford: Clarendon Press.

Billig, Michael 1995: Banal Nationalism. London: Sage.

Brubaker, Rogers 2020: "Populism and nationalism." Nations and nationalism 26: I, 44-66.

Butler, Judith 2006/1990: Hankala sukupuoli. Alkuteos Gender Trouble: Feminism and the Subversion of Identity. Suom. Tuija Pulkkinen ja Leena-Maija Rossi. Helsinki: Gaudeamus.

Halla-aho, Jussi 2005a: "Vähän rikollisuudesta vaihteeksi." Scripta 22.9.2005, http://halla-aho.com/scripta/vahan_rikollisuudesta_ vaihteeksi.html (viitattu 9.5.2019)

Halla-aho, Jussi 2005b: "Monikultturistinen vallankumous." Scripta 12.5.2005, http://www.halla-aho.com/scripta/monikultturistinen_ vallankumous.html (viitattu 9.5.2019) 
Halla-aho, Jussi 2005c: "Nöyryydestä todellisuuden edessä." Scripta 27.4.2005, http://www.halla-aho.com/scripta/noyryydesta_todellisuuden_edessa.html (viitattu 9.5.2019)

Halla-aho, Jussi 2005d: "Demografisista asioista ja muusta." Scripta 18.9.2005, http://www.halla-aho.com/scripta/demografisista_asioista_ja_muusta.html (viitattu 9.5.2019)

Halla-aho, Jussi 2006a: "Sivuston statistiikkaa siitä kiinnostuneille." Scripta 2.I2.2006, http://halla-aho.com/scripta/sivuston_statistiikkaa_siita_kiinnostuneille.html (viitattu 9.5.2019)

Halla-aho, Jussi 2006b: "Kuinka osaamispotentiaalia hyödynnetään?" Scripta 7.I.2006, http://www.halla-aho.com/scripta/kuinka_osaamispotentiaalia_hyodynnetaan.html (viitattu 9.5.2019)

Halla-aho, Jussi 2006c: "Diagnostiikka ja hoito suvaitsevaisittain." Scripta 30.4.2006, http://www.halla-aho.com/scripta/diagnostiikka_ja_hoito_suvaitsevaisittain.html (viitattu 9.5.2019)

Halla-aho, Jussi 2006d: "Valonpilkahduksia ja Mordorin yötä." Scripta 14.12.2006, http://www.halla-aho.com/scripta/valonpilkahduksia_ ja_mordorin_yota.html (viitattu 9.5.2019)

Halla-aho, Jussi 2006e: "Suvaitsematon syrjäytyneistö ja muuta ajankohtaista." Scripta 6.5.2006, http://www.halla-aho.com/scripta/suvaitsematon_syrjaytyneisto_ja_muuta_ajankohtaista.html (viitattu 9.5.2019)

Halla-aho, Jussi 2006f: "Moninaisuusmyönteinen yliopisto." Scripta 10.1 I.2006, http://www.halla-aho.com/scripta/moninaisuusmyonteinen_yliopisto.html (viitattu 9.5.2019)

Halla-aho, Jussi 2006g: "Lauantaisia haja-ajatuksia." Scripta 9.9.2006, http:// www.halla-aho.com/scripta/lauantaisia_haja-ajatuksia.html (viitattu 9.5.2019)

Halla-aho, Jussi 2007a: "Itsenäisyydestä." Scripta 5.12.2007, http://www. halla-aho.com/scripta/itsenaisyydesta.html (viitattu 9.5.2019)

Halla-aho, Jussi 2007b: "Ettei yksittäisyys unohtuisi." Scripta 4.9.2007, http://www.halla-aho.com/scripta/ettei_yksittaisyys_unohtuisi. html (viitattu 9.5.20l9)

Halla-aho, Jussi 2007c: "Suvaitsevaisia nyrjähdyksiä." Scripta 28.2.2007, http://www.halla-aho.com/scripta/suvaitsevaisia_nyrjahdyksia.html (viitattu 9.5.2019)

Halla-aho, Jussi 2008: "Somaleista globaalisti." Scripta I.2.2008, http:// www.halla-aho.com/scripta/somaleista_globaalisti.html (viitattu 9.5.2019)

Halla-aho, Jussi 2010a: "Puhe Perusnuorten populismipäivillä Turussa." Scripta 25.7.2010, http://www.halla-aho.com/scripta/puhe_perusnuorten_populismipaivilla.html (viitattu 9.5.2019)

Halla-aho, Jussi 20I0b: "Maahanmuuttoasenteista." Scripta 16.3.2010, http://www.halla-aho.com/scripta/maahanmuuttoasenteista.html (viitattu 9.5.2019)

Halla-aho, Jussi 20Ila: "Tilastoista ja etnopositiivisuudesta." Scripta 26.10.20 II, http://halla-aho.com/scripta/tilastoista_ja_etnopositiivisuudesta.html (viitattu 9.5.2019) 
Halla-aho, Jussi 20 I lb: "Katsaus julkilausuman kirvoittamiin kommentteihin." Scripta II.6.20I I, http://www.halla-aho.com/scripta/katsaus_julkilausuman_kirvoittamiin_kommentteihin.html (viitattu 9.5.2019)

Halla-aho, Jussi 2013: "Sosiaalidemokratiasta ja islamismista." Scripta 3.5.2013, http://www.halla-aho.com/scripta/sosialidemokratiasta_ ja_islamismista.html (viitattu 9.5.2019)

Halla-aho, Jussi 2015: "Muutama sana Pariisista." Scripta 8.I.20I5, http:// halla-aho.com/scripta/muutama_sana_pariisista.html (viitattu 9.5.2019)

Hatakka, Niko 2019: Populism in the Hybrid Media System: Populist Radical Right Online Counterpublics Interacting with Journalism: Party Politics and Citizen Activism. Turku:Turun yliopisto.

Hoggett, Paul \& Simon Thompson 2012: “Introduction.” In Paul Hoggett and Simon Thompson (eds.), Politics and the Emotions: The Affective Turn in Contemporary Political Studies, I-20. London: Continuum.

Hommaforum 2018: "Matalan intensiteetin kansanmurha." Hommawiki 18.5.20।8, https://wiki.hommaforum.org/wiki/Matalan_intensiteetin_kansanmurha (viitattu 30.8.2019)

Horsti, Karina \& Kaarina Nikunen 2013: "The Ethics of Hospitality in Changing Journalism: The Response to the Rise of the AntiImmigrant Movement in Finnish Media Publicity." European Journal of Cultural Studies 16(4), 480-504, https://doi.org/ 10.1177/13675494134917/8

Horsti, Karina \& Tuija Saresma 2020: "The Roe of Social Media in the Rise of Right-Wing Populism in Finland." In Howard Tumber and Silvio Waisbord (eds.), The Routledge Companion to Media Misinformation and Populism. Hyväksytty julkaistavaksi.

Hutcheon, Linda 1986: Theory of Parody:The Teachings of Twentieth-Century Art Forms. London: Methuen.

Hutcheon, Linda 1994: Irony's Edge:The Theory and Politics of Irony. Abingdon: Routledge.

Iltalehti 2019: "Jussi Halla-aho aktivoi kohubloginsa ensimmäistä kertaa puheenjohtajana: 'Loikkareille ottaa politiikassa melkein aina ohraleipä.." Iltalehti 19.4.2019, https:/www.iltalehti.fi/politiikka/ a/5 I c2 I886-5d99-4492-b002-I I eabb97ea I a (viitattu 26.8.2019)

Iltalehti 2018: "Juha Sipilä käytti oikeistopopulistien suosikkitermiä 'vihervasemmisto' aseenaan - Li Andersson ja Ville Niinistö tulistuivat: 'Todellinen rimanalitus'.' Iltalehti 22.8.2018, https://www.iltalehti.fi/ politiikka/a/20I80822220I I 52083 (viitattu 26.8.20I9)

Ilta-Sanomat 2019: "Kommentti: Halla-aho löysi edestään jälleen vanhat blogitekstinsä - onko PS:n ja Sdp:n 'arvokuilu' Rinteelle liikaa?" Iltasanomat 17.4.2019, https://www.is.fi/politiikka/art2000006076004.html (viitattu 26.8.2019)

Keskinen, Suvi 2012: "Limits to Speech? The Racialized Politics of Gendered Violence in Denmark and Finland." Journal of Intercultural Studies 33(3), 26I-274. 
Kivimäki, Sanna, Marjo Kolehmainen \& Johanna Sumiala 20 I0: "Tunteet ja tutkimus." Pääkirjoitus. Media \& viestintä 33: 4, 2-6.

Knuutila, Aleksi, Tuija Saresma \& Heidi Kosonen 2019: Viha vallassa. Vihapuheen vaikutukset yhteiskunnalliseen päätöksentekoon. Helsinki: Valtioneuvoston kanslian tutkimus- ja selvitystoiminta.

Laclau, Ernesto 2005: On Populist Reason. London: Verso.

Maasilta, Mari \& Kaarina Nikunen (toim.) 2018: Pakolaisuus, tunteet ja media. Tampere: Vastapaino.

Maussen, Marcel \& Ralph Grillo 2014: "Regulation of Speech in Multicultural Societies: Introduction." Journal of Ethnic and Migration Studies 40: 2, 174-193.

Nikunen, Kaarina: 2015: "Politics of Irony as the Emerging Sensibility of the Anti-Immigrant Debate." In Rikke Andreassen and Kathrine Vitus (eds.), Affectivity and Race: Studies from Nordic Contexts, 2 I-42. Farnham:Ashgate.

Nikunen, Kaarina \& Mervi Pantti 2018: "Tapaus Ku Klux Klan. Affektiivinen julkisuus, moraaliset tunteet ja tahmaiset kuvat." Teoksessa Kaarina Nikunen ja Mari Maasilta (toim.), Pakolaisuus, tunteet ja media, 7I-9I.Tampere: Vastapaino.

Ovaskainen, Teppo 2019: 'PS-Nuorten johtohahmo ohjaisi 'ei-valkoiset' ulos maasta - Järjestö kieli keskellä suuta.” Uusi Suomi 02.1.2019, https://www.uusisuomi.fi/kotimaa/2682 I4-ps-nuorten-johtohahmo-ohjaisi-ei-valkoiset-ulos-maasta-jarjesto-kieli-keskella-suuta (viitattu 28.8.2019)

Paananen, Veera 2019: "Jussi Halla-aho yhdisti Tullin harjoituksen ja alHolin kotiuttamisen, tulli kertoi poikkeuksellisen laajasta disinformaatiokampanjasta - näin Halla-aho vastaa." Helsingin Sanomat 12.12.2019, https://www.hs.fi/politiikka/art-200000634I I80.html (viitattu 3I.I.2020)

Palonen, Emilia \& Tuija Saresma (toim.) 2017: Jätkät ja jytkyt. Perussuomalaiset ja populistinen retoriikka. Tampere: Vastapaino.

Palonen, Emilia \& Tuija Saresma 2019: "Kansallinen ja ylirajainen populismi. eliitinvastaisuutta, anti-intellektuellismia, EU-kriittisyyttä ja naisvihaa.” Teoksessa Antti Ronkainen ja Juri Mykkänen (toim.), Vapiseva Eurooppa. Mitä seuraa eurooppalaisen politiikan kaaoksesta, I I I-I 25. Tampere:Vastapaino.

Parekh, Bhikhu 2012: "Is There a Case for Banning Hate Speech?" In Michael Hertz and Peter Molnar (eds.), The Content and Context of Hate Speech: Rethinking Regulation and Responses, 37-50. Cambridge: Cambridge University Press.

Parkkinen, Laura 2017: "Timo Soinin Kaanaan kieli - Pelastuksen politiikkaa ja saarnapuhetta." Teoksessa Emilia Palonen ja Tuija Saresma (toim.), Jätkät ja jytkyt, 273-296. Tampere: Vastapaino.

Perussuomalaisten eduskuntaryhmä 20I I: Julkilausuma syrjintää, rasismia ja väkivaltaa vastaan. 25.5.20II, https://yle.fi/tvuutiset/uutiset/ upics/liitetiedostot/julkilausuma.pdf

Pettersson, Katarina 2017: Save the Nation! A Social Psychological Study of Political Blogs as a Medium for Nationalist Communication and Persuasion. Helsinki: Helsingin yliopisto. 
Pullinen, Jussi 2019: "Essee: Huvittunut sivullinen syö naksuja." Helsingin Sanomat I5.12.2019, https://www.hs.fi/sunnuntai/art2000006342832.html (viitattu 3I.I.2019)

Rautio, Yrjö 2019: "Oikeistopopulistit toistelevat teemoja, joilla natsit nousivat valtaan Saksassa." Helsingin Sanomat 16.8.2019, https:// www.hs.fi/politiikka/art-200000620599I.html (viitattu I.9.2019)

Saresma, Tuija 2016: "Vihan ja kaunan tunneyhteisöt. Timo Hännikäisen IIman-kokoelman affektiivinen esseistiikka." Teoksessa Anna Helle ja Anna Hollsten (toim.), Tunteet ja tuntemukset suomalaisessa kirjallisuudessa, 22 I-246. Helsinki: SKS.

Saresma,Tuija 20I7a:"Väkivaltafantasiat ja pelon politiikka. Sukupuolitetun ja sukupuolittavan verkkovihapuheen luentaa." Teoksessa Sanna Karkulehto ja Leena-Maija Rossi (toim.), Sukupuoli ja väkivalta. Lukemisen etiikkaa ja politiikkaa, 22 I-246. Helsinki: SKS.

Saresma, Tuija 20 I7b: "Sananvapaus, vihapuhe ja sananvastuu." Teoksessa Kari Enqvist, llari Hetemäki ja Teija Tiilikainen (toim.), Kaikki vapaudesta, 35-53. Helsinki: Gaudeamus.

Saresma, Tuija 2018: "Politics of Fear and Racialized Rape: Intersectional Reading of the Kempele Rape Case." In Peter Hervik (ed.), Racialization, Racism, and Anti-Racism in the Nordic Countries, 63-9I. London: Palgrave Macmillan, https://doi.org//0.1007/9783-319-74630-2_3

Saresma, Tuija 2020: "Vihan sfäärit. Valkoisten heteromiesten affektiivinen mobilisaatio sosiaalisessa mediassa." Teoksessa Jenni Rinne, Anna Kajander ja Riina Haanpää (toim.), Affektit ja tunteet kulttuurien tutkimuksessa, 196-243. Helsinki: Ethnos.

Soini, Timo 2007: Kolme Goljatia ja oma työ. Ploki 2.3.2007, http://timosoini.fi/2007/03/kolme-goljatia-ja-oma-tyo/ (viitattu 16.9.2019)

Stavrakakis, Yannis, Giorgos Katsambekis, Nikos Nikisianis, Alexandros Kioupkiolis \& Thomas Siomos 2017: "Extreme Right-wing Populism in Europe: Revisiting a Reifies Association." Critical Discourse Studies 14: 4, 420-439.

Stenroos, Maria \& Tulikukka de Fresnes 2017: "Halla-aho korostaa kansallismielisyyttä eikä irtisanoudu vanhoista blogiteksteistään 'Afrikan sarven ihmissaasta' ei ollut hänestä loukkaavaa kieltä." Yle Uutiset II.6.20I7, https://yle.fi/uutiset/3-9663454 (viitattu 20.9.2019)

Suomen Uutiset 2018: "Halla-aho: Puhe väestönvaihdoksesta ei ole foliohattuilua tai liioittelua." Suomen Uutiset 17.4.2018, https://www. suomenuutiset.fi/halla-aho-puhe-vaestonvaihdoksesta-foliohattuilua-liioittelua/ (viitattu 28.8.2019)

Torvinen, Pekka 2019: "Analyysi. Väestönvaihto on salaliittoteoria, mutta se ei estä perussuomalaisten johtoa käyttämästä sanaa." Helsingin Sanomat, NYT-liite 5.7.2019, https://www.hs.fi/nyt/art2000006 I63786.html (viitattu 28.8.2019)

Tuusvuori, Jarkko 2017: "Maahanmuuttajien vastustaminen ei ole kriittisyyttä." niin \& näin 2, http://netn.fi/artikkeli/maahanmuuttajien-vastustaminen-ei-ole-kriittisyytta (viitattu 20.9.2019) 
Uusi Suomi 2019: "Tutkija tarttui perussuomalaisen tviittiin. 'Jos joku on halunnut uskoa PS:n olevan normaali puolue, nyt kannattaa kohdata tosiasiat."' Uusi Suomi 10.8.2019, https://www.uusisuomi. fi/kotimaa/287559-tutkija-tarttui-perussuomalaisen-tviittiinjos-joku-halunnut-uskoa-psn-olevan (viitattu 28.8.2019)

Vaarakallio, Tuula 2017: "Perussuomalaisten kaksoispuhe." Teoksessa Emilia Palonen ja Tuija Saresma (toim.), Jätkät ja jytkyt: Perussuomalaiset ja populistinen retoriikka, 199-2 17. Tampere: Vastapaino.

Vainikka, Eliisa 2019: Naisvihan tunneyhteisö. Anonyymisti esitettyä verkkovihaa Ylilaudan ihmissuhdekeskusteluissa. Media \& viestintä 4, I-25.

Van Dijk, Teun 1993:"Principles of Critical Discourse Analysis.” Discourse \& Society 4: 2, 249-283.

Vänni, Leena 2009: Yhteisöllisyyden ilmeneminen verkkokeskustelussa. Tarkastelussa yhteiskuntakriittisen keskustelufoorumin sanasto. Julkaisematon pro gradu -tutkielma.Vaasan yliopisto.

Wimmer, Andreas 2002: Nationalist Exclusion and Ethnic Conflict: Shadows of Modernity. Cambridge: Cambridge University Press.

Wolfe, Kristin 2014: Blogging: How Our Private Thoughts Went Public. Lanham: Lexington Books.

Ylä-Anttila, Tuukka 2017: The Populist Toolkit: Finnish Populism in Action 2007-20 /6. Helsinki: Helsingin yliopisto.

\section{Kirjoittajat}

Tuija Saresma, dosentti, yliopistotutkija, Jyväskylän yliopisto.

tuija.saresma@jyu.fi

Urho Tulonen, projektitutkija, Jyväskylän yliopisto.

urho.h.tulonen@jyu.fi 
<smiles>C=CC</smiles> 